\title{
Response of Tobacco Farmer to PMUP (Participative Model of Farming Activity) in Tlahab Village, Kecamatan Kledung, Kabupaten Temanggung
}

Andrie Arfianto ${ }^{1}$

\begin{abstract}
Agricultural sustainable development is an integrated effort to support agricultural activities by involving stakeholders with different backgrounds and motives; such as social, cultural, economic, and environmental. Participatory Farming Model Development (Pengembangan Model Usahatani Partisipatif - PMUP) conducted by the government in Desa Tlahab intended to improve the farmer welfare by increasing income without sacrificing the heritage of tobacco farming culture while reducing the environmental damage caused by tobacco cultivation. This kind of agricultural activities need immense participation and willingness of the farmers as a supporting response for the implementation of this system on their land. Farmers stated that living conditions have kept them from supporting the implementation of PMUP. This condition includes farmer socio-economic situation, environmental conditions in carrying out the activities, the low performance of farmer groups, lack of competitiveness of the PMUP compared to previous agricultural system, also lack of performance from the institutional boards.
\end{abstract}

Keywords: agricultural sustainable development, agricultural diversification, tobacco farmer responses, regional potential development

\section{PENDAHULUAN}

Perkembangan kondisi suatu wilayah tidak akan lepas dari cara dan usaha pemerintah dan masyarakat di wilayah tersebut dalam menggali potensi yang dimilikinya, kondisi tersebut juga terjadi di wilayah Kabupaten Temanggung. Kabupaten Temanggung memiliki luas $870,65 \mathrm{~km}^{2}$, memiliki bentang alam wilayah berada di ketinggian 400-1.450 mdpl, dengan suhu antara 20-30 ${ }^{\circ} \mathrm{C}$ dan bercurah hujan cukup tinggi. Kondisi lingkungan ini cukup mendukung dan memberikan nilai lebih bagi masyarakat Kabupaten Temanggung dalam mengembangkan potensi di sektor pertanian. Pada tahun 2009, sektor pertanian menyumbang 31,75\% pendapatan regional Kabupaten Temanggung, jauh di atas kontribusi sektor-sektor lainnya (industri pengolahan sebesar 19,52\%, perdagangan sebesar 16,74\%, dan jasa-jasa sebesar 14,33\%). Komoditas pertanian unggulan khas Kabupaten Temanggung yang masih diperhitungkan adalah tembakau. Budidaya tembakau Kabupaten Temanggung dilaksanakan di 14 kecamatan dari 20 kecamatan yang ada. Di satu sisi keberadaan aktifitas budidaya tanaman tembakau mampu membangkitkan kegiatan perekonomian yang terkait langsung maupun tak langsung dengan budidaya tembakau, antara lain industri pengolahan perajangan tembakau dan aktifitas industri bahan penunjang seperti industri keranjang bambu sebagai kemasan. Sektor perdagangan-pun ikut berkembang pesat melalui aktifitas perdagangan baik dalam skala modal kecil maupun besar. Pesatnya aktifitas perdagangan komoditas tersebut juga mendorong aktifitas bersifat jasa seperti pergudangan dan angkutan barang.

\footnotetext{
${ }^{1}$ Andrie Arfianto adalah Staf di Pemda Kabupaten Temanggung, Jawa Tengah 
Di sisi lain, perkembangan budidaya tembakau di Kabupaten Temanggung menimbulkan beberapa permasalahan, baik yang dirasakan oleh masyarakat maupun pemerintah Kabupaten Temanggung. Permasalahan budidaya tembakau di Kabupaten Temanggung yang selama ini dialami adalah: (1) menurunnya produktifitas tembakau dan hasil usaha tani lain karena tingkat kesuburan tanah turun, (2) meningkatnya biaya usaha tani karena degradasi daya dukung lahan, dan (3) semakin meluasnya kerusakan sumber daya alam, khusunya pada areal penanaman dengan kemiringan di atas $40 \%$ di lereng-lereng gunung Sumbing-Sindoro-Prau. Ada beberapa usaha dan kegiatan yang dilaksanakan oleh pemerintah dan masyarakat dalam menanggulangi dampak negatif akibat budidaya tanaman tembakau. Sebuah program yang cukup menarik untuk diamati adalah kegiatan Pengembangan Model Usahatani Partisipatif (PMUP). Kegiatan PMUP dilakukan dengan mengembangkan tanaman tahunan secara berdampingan (tumpang sari) di lahan budidaya tembakau, yaitu kopi arabika dan suren. Pola tanam ini diharapkan akan mampu mengurangi tingkat degradasi lahan dan juga memberikan alternatif sumber pendapatan lain bagi petani. Kegiatan ini dilengkapi dengan bantuan kepada masyarakat, meliputi bantuan benih, pupuk, obat-obatan, permodalan, pembinaan teknik budidaya dan pemasaran produksi yang dihasilkan. Oleh karenanya, pengembangan pola tanam ini diharapkan dapat memberikan manfaat secara ekonomi dengan memperluas alternatif pendapatan para petani tembakau. Kegiatan PMUP di Desa Tlahab dilaksanakan dengan memberdayakan petani tembakau dalam melakukan aktifitas usaha taninya dengan tetap memperhatikan kondisi lingkungan.

Respon petani tembakau terhadap program kegiatan PMUP yang dikembangkan pemerintah Kabupaten Temanggung akan menarik untuk dikaji. Karena kondisi sosial ekonomi petani tembakau dengan pola kehidupan berkonsep pertanian tembakau tradisional, petani cenderung tidak terlalu memperhatikan masalah kelestarian lingkungan dan hanya memusatkan perhatian pada komoditi tembakau. Sementara itu di sisi lain, ada sebuah inisiatif pemerintah daerah Kabupaten Temanggung yang mencetuskan kebijakan pertanian berkelanjutan dengan program agroekologi dan diversifikasi usahatani melalui kegiatan PMUP di lahan petani yang menjadi modal utama mereka dalam melangsungkan kehidupannya.

\section{METODE PENELITIAN}

Jenis penelitian ini merupakan penelitian deskriptif kualitatif yaitu sebuah penelitian tentang data yang dikumpulkan dan dinyatakan dalam bentuk kata-kata dan gambar. Menurut Sugiyono (2010), penelitian kualitatif didefinisikan sebagai sebuah metode penelitian yang digunakan untuk meneliti pada kondisi objek yang alamiah dimana peneliti adalah sebagai kunci dengan teknik pengumpulan data dilakukan secara triangulasi (gabungan), analisis data bersifat induktif dan hasil penelitian kualitatif lebih menekankan kepada makna daripada generalisasi. Adapun konsentrasi dari masukan data primer yang dibutuhkan tetap sesuai dengan variabel penelitian yang telah diterapkan sebelumnya, yaitu berkisar pada identifikasi sistem agribisnis pertanian di Desa Tlahab dalam pelaksanaan kegiatan PMUP serta karakteristik masyarakat yang dapat mempengaruhi respon masyarakat terhadap kegiatan PMUP. Analisis yang digunakan adalah analisis deskriptif terhadap data yang bersifat kualitatif untuk mendapatkan deskripsi mengenai peran kelembagaan pada masing-masing sasaran. 


\section{GAMBARAN UMUM WILAYAH STUDI}

Wilayah sasaran penelitian adalah di Desa Tlahab Kecamatan Kledung, Kabupaten Temanggung. Desa ini menjadi salah satu sentra aktifitas pertanian khususnya tembakau yang ditandai dengan tingginya produksi tembakau dan luasan lahannya. Pada tahun 2009, lahan tembakau di Desa Tlahab seluas 224 ha, di atas rata-rata luas lahan tembakau di Kecamatan Kledung sebesar 144,38 ha. Produksi tembakaunya mencapai 140 ton, di atas rata-rata produksi sebesar 86,923 ton (BPS, 2010). Untuk memberikan gambaran yang lebih jelas tentang ruang lingkup wilayah penelitian, dapat dilihat pada Gambar 1 di bawah ini.

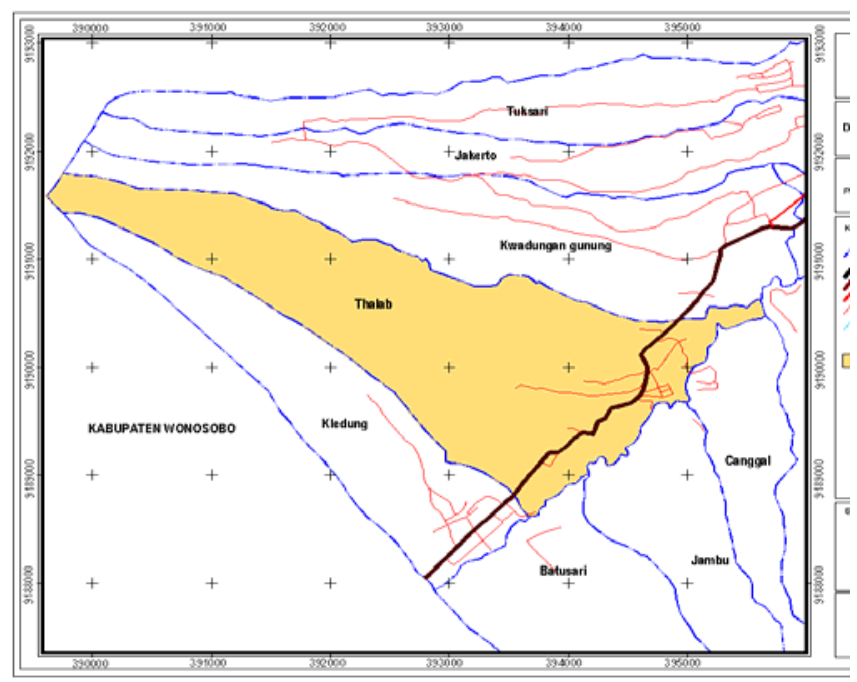

Sumber: Bappeda Kab. Temanggung, 2008

GAMBAR 1

PETA ADMINISTRASI DESA TLAHAB KECAMATAN KLEDUNG KABUPATEN TEMANGGUNG

\section{KAJIAN LITERATUR}

Perubahan sikap dapat menggambarkan respon seseorang atau sekelompok orang terhadap objek-objek tertentu. Sikap yang muncul dapat positif yakni cenderung menyenangi, mendekati, dan mengharapkan suatu objek, seseorang disebut mempunyai respon positif dilihat dari tahap kognisi, afeksi, dan psikomotorik. Sebaliknya seseorang mempunyai respon negatif apabila informasi yang didengarkan atau perubahan suatu objek tidak mempengaruhi tindakan atau malah menghindar dan membenci objek tertentu. Terdapat dua jenis variabel yang mempengaruhi respon, yaitu: variabel struktural yakni faktor-faktor yang terkandung dalam rangsangan fisik, dan variabel fungsional yakni faktor-faktor yang terdapat dalam diri si pengamat, misalnya kebutuhan suasana hati, pengalaman masa lalu (Cruthefield, dalam Sarwono, 1991). Oleh karena itu, dapat diambil pengertian bahwa respon petani terhadap kegiatan pola tanam tembakau dengan sistem berbeda jika dibandingkan dengan pola tanam sebelumnya, dapat dilihat dari dinamika pemahaman, kesadaran, serta peran serta dan partisipasi mereka dalam pelaksanaan kegiatan. Dan semua itu berpengaruh pada keberlanjutan pembangunan oleh mereka sendiri.

Bloom dalam Notoatmodjo (1993) menyatakan bahwa perilaku seseorang terdiri dari tiga bagian penting, yaitu kognitif, afektif, dan psikomotor. Kognitif dapat diukur dari 
pengetahuan, afektif dari sikap, dan psikomotor diukur melalui tindakan (praktek) yang dilakukan. Respon seseorang terhadap suatu hal atau aktifitas adalah bagaimana seseorang menanggapi suatu hal atau aktifitas dengan memersepsi, mengetahui, menyikapi hal atau aktifitas sebagai bentuk respon atau anggapan pasif dan bagaimana seseorang bertindak/ praktek nyata terhadap hal atau aktifitas tersebut sebagai bentuk respon atau tanggapan aktifnya. Jadi, yang dimaksud dengan respon masyarakat yang dalam pengertian penelitian ini adalah para petani tembakau adalah tingkah laku balas atau tindakan masyarakat yang merupakan wujud dari persepsi, sikap, dan partisipasi masyarakat terhadap suatu objek, dalam hal ini adalah kegiatan Pengembangan Model Usahatani Partisipatif (PMUP) yang dapat dilihat melalui proses pemahaman, penilaian, pengaruh atau penolakan, suka atau tidak suka, serta pemanfaatan terhadap objek tersebut.

\section{ANALISIS PELAKSANAAN KEGIATAN PMUP DI DESA TLAHAB}

\section{Pelaksanaan Kegiatan PMUP Tahun 2000-2004}

Kegiatan PMUP Desa Tlahab mulai dilaksanakan oleh Dinas Perkebunan (Disbun) Provinsi mulai tahun anggaran 2000-2004 dengan pelaksanaan teknis PMUP 2000-2004 dapat dilihat pada Kegiatan PMUP terbagi menjadi 2 jenis kegiatan yaitu kegiatan fisik, yaitu pelaksanaan teknis kegiatan di lapangan dan bantuan komoditi (bibit kopi arabika, suren, rumput gajah) serta kegiatan non fisik meliputi pengawasan dan penyuluhan oleh petugas penyuluh pertanian kepada petani, terkait teknik penanaman, pemeliharaan, dan perawatan terhadap komoditi yang terkait dengan PMUP tersebut.

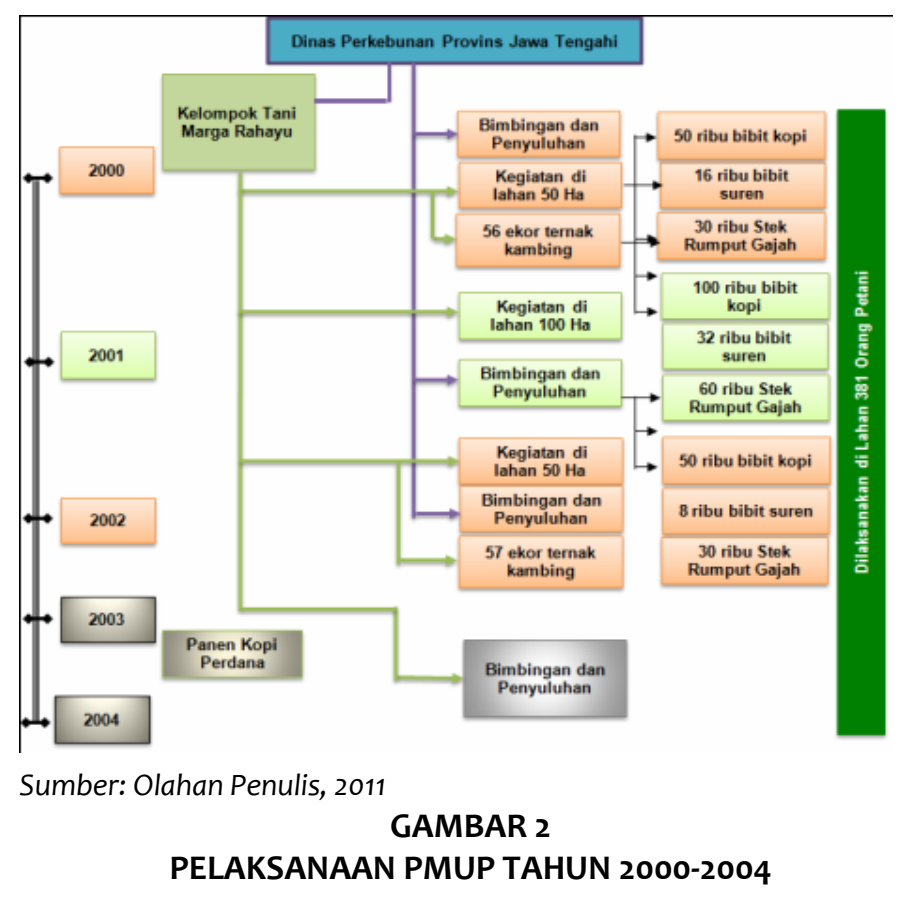

Pelaksanaan PMUP 2000-2004 melibatkan 381 petani yang saat itu menjadi anggota kelompok tani Marga Rahayu dengan total luas lahan selama 5 tahun kegiatan seluas 200 hektar. Pelaksanaan kegiatan PMUP 2000-2004 cenderung top down dimana Dinas Perkebunan Provinsi melaksanakan semua pelaksanaan PMUP, mulai dari perencanaan teknis kegiatan, pelaksanaan teknis penanaman di lahan, pemeliharaan dan perawatan sampai dengan pelaksanaan penyuluhan kepada petani, baik pada saat pelaksanaan kegiatan di lahan maupun 
pada saat kegiatan di lahan sudah selesai dilaksanakan. Bimbingan pasca pelaksanaan kegiatan lebih dimaksudkan untuk mengubah pola pikir dan pemahaman petani terhadap kultur pola tanam petani yang sebelumnya sangat berorientasi kepada tanaman tembakau, kemudian mulai diperkenalkan kepada pola tanam yang terintegrasi dengan melaksanakan diversifikasi pola tanam, memadukan tanaman tembakau sebagai tanaman utama dengan tanaman kopi arabika, pohon suren dan rumput gajah.

\section{Pelaksanaan Kegiatan PMUP Tahun 2009}

Distanbunhut Kabupaten Temanggung melaksanakan kembali kegiatan PMUP di Desa Tlahab pada tahun anggaran 2009. Secara prinsip, kegiatan PMUP Distanbunhut tidak memiliki perbedaan yang signifikan. Pelaksanaan PMUP 2009 melibatkan 42 petani yang menjadi anggota kelompok tani Daya Sindoro dengan luas lahan 25 hektar. Proporsi tanaman yang ditanam yaitu kopi arabika:suren:rumput gajah adalah sebesar 1.200:320:2.000. Proporsi ini lebih banyak jika dibandingkan kegiatan PMUP 2000-2004. Perbedaan proporsi tanaman yang ada menimbulkan konsekuensi berkurangnya tanaman tembakau yang dapat ditanam oleh petani di lahannya. Sementara itu jika dilihat dari waktu pelaksanaannya, PMUP 2009 dimulai pada bulan Agustus dan berakhir pada bulan Desember. Pelaksanaan kegiatan yang cenderung dilaksanakan pada bulan akhir tahun dimaksudkan agar kegiatan dapat dilaksanakan tanpa terganggu oleh musim tanam tembakau sampai dengan pengolahan pasca panen yang biasanya baru berakhir pada bulan Juli - Agustus.

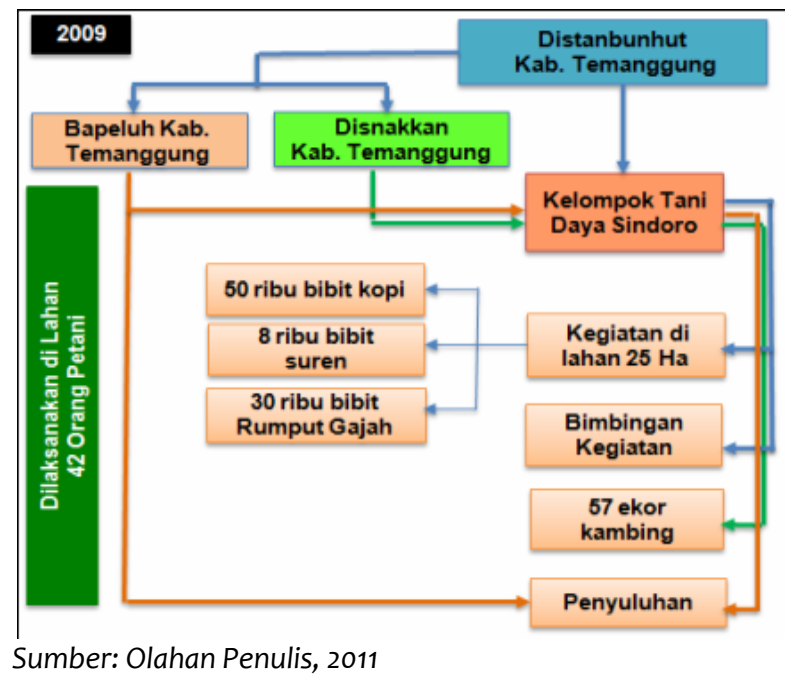

\section{GAMBAR 3 \\ PELAKSANAAN PMUP TAHUN 2009}

PMUP 2009 dilaksanakan oleh beberapa dinas terkait sesuai dengan tugas pokok dan fungsi tiap dinas yang telah ditetapkan dalam Perda Kabupaten Temanggung Nomor 25 Tahun 2008 tentang Tata Kerja Dinas Daerah Kabupaten Temanggung. Hal ini sedikit berbeda dengan saat pelaksanaan PMUP oleh Dinas Perkebunan Provinsi yang relatif tidak memerlukan banyak koordinasi dengan pihak lain. PMUP 2009 melibatkan secara langsung Distanbunhut sebagai leading sector pelaksanaan kegiatan, Dinas Peternakan dan Perikanan (Disnakkan) sebagai pengelola bantuan ternak kambing kepada petani dan Badan Penyuluh Pertanian, Perikanan dan Kehutanan (Bapeluh) sebagai pihak yang memberikan penyuluhan. Kegiatan PMUP yang dilaksanakan oleh Distanbunhut Kabupaten Temanggung selama 1 tahun anggaran tidak memberi banyak waktu bagi dinas terkait, khususnya Distanbunhut untuk melakukan 
pemantauan pasca kegiatan teknis. Penanaman di lahan pertanian yang berakhir pada pertengahan bulan Desember dan kemudian dilaksanakan pemeliharaan selama 2 minggu sampai dengan tahun anggaran 2009 berakhir. Kegiatan non teknis dilaksanakan sebatas pelaksanaan pengawasan kegiatan agar dapat berjalan sesuai dengan ketentuan teknis dan rencana kegiatan.

\section{ANALISIS SISTEM AGRIBISNIS DI DESA TLAHAB BERDASARKAN MODEL KEGIATAN PMUP}

Sebagai kegiatan yang menyangkut kehidupan dan mata pencaharian masyarakat khususnya petani, PMUP memiliki sistem agribisnis yang memproduksi, mengolah, dan memasarkan komoditi sehingga petani menerima pendapatan dari kegiatan usahanya. Perlu untuk dikaji pendapatan dan keuntungan yang diterima dan biaya yang harus dikeluarkan oleh petani apabila mengintegrasikan beberapa komoditi.

\section{Pendapatan Petani dari Komoditi Tembakau di Lahan Non PMUP}

Dari budidaya tembakau di lahan non PMUP, dapat dilihat biaya yang harus dikeluarkan serta pendapatan dan keuntungan yang diperoleh para petani di musim tanam 2011. Petani mendapat keuntungan yang cukup besar yaitu sekitar Rp 40.611.000,- di musim tanam 2011. Diakui oleh para petani, harga tembakau di musim tanam 2011 merupakan harga terbaik dalam kurun waktu 5 tahun terakhir. Selain bertambahnya pendapatan, konsekuensi meningkatnya harga jual tembakau tahun ini adalah meningkatnya harga beli input produksi, seperti pupuk, baik organik maupun non organik, obat-obatan, keranjang maupun upah tenaga kerja. Sehingga apabila dihitung, keuntungan petani saat ini relatif sama bahkan cenderung turun.

Kondisi usahatani tembakau di Desa Tlahab jika dengan pola seperti sekarang, akan memunculkan permasalahan bagi petani yang tergantung kepada tembakau, dengan asumsi pola agribisnis tetap seperti sekarang dimana pendapatan tetap Rp 76.950.000,- . Mulai tahun 2014 jumlah pengeluaran petani akan lebih besar dibandingkan keuntungan yang diterima, jumlah biaya sebesar Rp 40.357.907,-- dengan keuntungan sebesar Rp 36.592.093,- . Kondisi ini terus berlanjut sampai dengan tahun 2021 dimana pada saat itu biaya produksi akan melebihi pendapatan yang diterima yaitu Rp 80.436.958,-. Sehingga pada musim tanam 2021 petani tembakau akan merugi sebesar Rp 3.486.958,-. Tren pendapatan, biaya, dan keuntungan yang dapat diperoleh petani dapat dilihat pada Gambar 4 berikut.

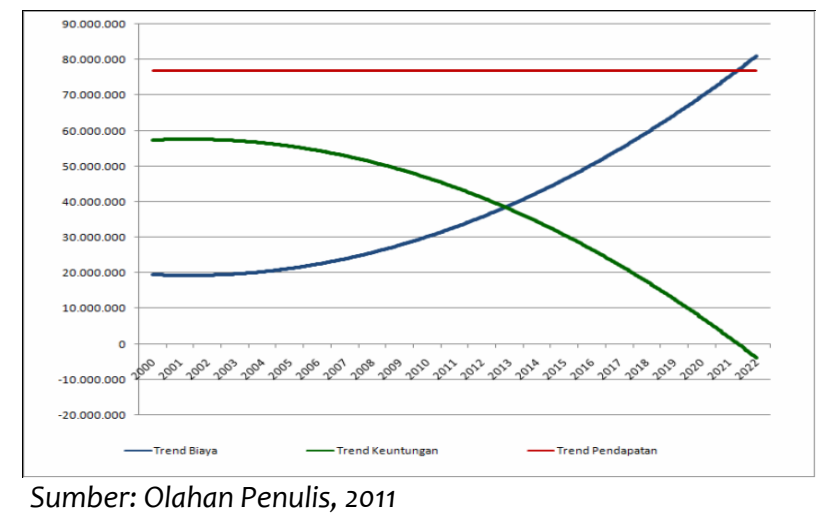

GAMBAR 4

TREN BIAYA, PENDAPATAN DAN KEUNTUNGAN USAHATANI TEMBAKAU 


\section{Pendapatan Petani dari Pelaksanaan PMUP}

Pembahasan sistem agribisnis dari setiap komoditi dalam PMUP di atas, dapat dihasilkan perhitungan total biaya, pendapatan, dan keuntungan yang diterima oleh petani pelaksana kegiatan PMUP dalam kurun waktu 11 tahun, mulai dari awal pelaksanaan PMUP pada tahun 2000, semua komponen baik biaya, pendapatan, dan keuntungan petani sudah mengalami kenaikan sampai dengan tahun terakhir, hal tersebut seiring dengan semakin bertambahnya hasil panen tanaman tahunan yang juga disertai kenaikan biaya yang harus dikeluarkan. Perbandingan pendapatan dan biaya petani dengan analisis $\mathrm{R} / \mathrm{C}$ ratio, menunjukkan PMUP memiliki nilai > 1 yang berarti kegiatan usaha tersebut mengalami keuntungan usaha. $B / C$ ratio sebagai indikator perhitungan nilai kemanfaatan dan efektivitas dari kegiatan usahatani yang memiliki nilai rata rata $<1$, hanya di tahun pertama dan kedua nilai $\mathrm{B} / \mathrm{C}$ ratio $>1$. Nilai $\mathrm{B} / \mathrm{C}$ ratio $<$ 1 mengindikasikan ketidakefisienan kegiatan usaha dan dalam jangka panjang tidak menguntungkan, sementara di tahun yang lain selalu di bawah kegiatan non PMUP.

Jika dibandingkan dengan kegiatan agribisnis non PMUP, biaya yang harus dikeluarkan oleh petani pelaksana PMUP mulai tahun pertama telah melebihi kegiatan non PMUP yaitu 102,78\%, dan selanjutnya terus bertambah sampai tahun 2005 dengan persentase tertinggi yaitu 149,08\%, bahkan sampai dengan tahun 2011 biaya yang dkeluarkan petani dalam pelaksanaan PMUP tetap lebih besar yaitu $123,39 \%$. Besarnya biaya yang harus dibayarkan oleh para petani menimbulkan permasalahan tersendiri, karena kondisi petani yang mengalami kendala dalam mendapatkan modal. Analisa di atas menunjukkan bahwa manfaat pelaksanaan agribisnis model PMUP di Desa Tlahab, secara ekonomi baru dapat dirasakan dalam jangka waktu yang cukup panjang, yaitu tahun kesepuluh. Sehingga apabila pemerintah daerah menginginkan petani mau melaksanakan kegiatan PMUP dengan motif ekonomi harus dilakukan inovasi dan terobosan yang dapat mmberikan subsidi dan insentisf bagi petani sebagai kompensasi pengganti atas hilangnya potensi keuntungan yang dapat diterima jika mereka melaksanakan model usahatani non PMUP.

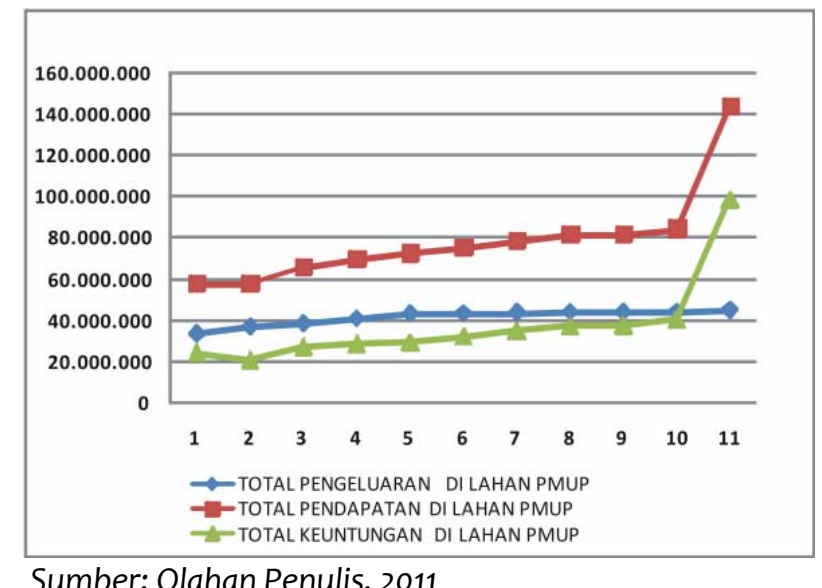

Sumber: Olahan Penulis, 2011

GAMBAR 5

GRAFIK BIAYA, PENDAPATAN DAN KEUNTUNGAN KEGIATAN PMUP DI DESA TLAHAB 


\section{ANALISIS KERUANGAN KEGIATAN PMUP DI DESA TLAHAB, KECAMATAN KLEDUNG, KABUPATEN TEMANGGUNG}

Menurut rencana pola ruang Peraturan Daerah Kabupaten Temanggung Nomor 5 Tahun 2008 tentang Rencana Tata Ruang Wilayah (RTRW) Kabupaten Temanggung Tahun 2008-2028, Desa Tlahab sebagai wilayah Kecamatan Kledung sebagian besar peruntukannya adalah sebagai kawasan lindung yang terdiri dari kawasan hutan lindung dan kawasan lindung yang memberikan perlindungan terhadap kawasan dibawahnya, serta kawasan budidaya yang terdiri dari kawasan peruntukan pemukiman, hutan produksi terbatas dan sawah non irigasi. Dengan membandingkan ketentuan dalam RTRW Kabupaten Temanggung dan kondisi eksisting Desa Tlahab, dapat dikatakan bahwa terjadi penggunaan lahan yang tidak sesuai dengan ketentuan peraturan tata ruang yang ada, terlihat ada beberapa spot di Desa Tlahab yang tidak sesuai untuk dijadikan lahan pertanian kering. Kondisi tersebut sangat beresiko karena kondisi ini dapat menimbulkan permasalahan.

Untuk mengurangi terjadinya penurunan kualitas lahan tersebut di atas pemerintah mengambil langkah melaksanakan konservasi dengan mengembangkan tanaman tahunan dengan tetap memperhatikan kultur budaya masyarakat setempat khususnya para petani yang telah bercocok tanam tembakau sejak dulu, serta meningkatkan taraf ekonomi dan kehidupan petani. Kegiatan PMUP merupakan program alternatif yang dirintis pemerintah tahun $2000 \mathrm{di}$ Desa Tlahab Kecamatan Kledung Kabupaten Temanggung yang bertujuan meningkatkan pendapatan petani melalui penerapan usahatani tembakau lebih intensif, efisien, dan berorientasi pada pelestarian sumber daya alam. Dengan telah dilaksanakannya PMUP di Desa Tlahab selama 12 tahun terakhir, seharusnya kerusakan lingkungan akibat budidaya tembakau dapat diminimalisir. Akan tetapi data tentang kandungan bahan organik dan biaya produksi dalam hal ini kebutuhan pupuk di Desa Tlahab selama 12 tahun terakhir menunjukkan, tingkat kesuburan tanah terus mengalami penurunan. Kondisi ini menunjukkan upaya pelestarian lingkungan oleh pemerintah melalui pelaksanaan PMUP di Desa Tlahab dapat dikatakan belum berhasil. Kondisi tersebut disebabkan selain karena respon petani dalam melaksanakan model PMUP di lahannya belum optimal, juga disebabkan proporsi tanaman tembakau di lahan petani yang masih cukup besar, yaitu sekitar $75 \%$ dari total luas lahan yang dimiliki oleh petani pelaksanan kegiatan PMUP.

\section{ANALISIS KEBERLANJUTAN PELAKSANAAN PMUP}

Pelaksanaan PMUP di Desa Tlahab menjadi sebuah contoh sebuah kegiatan yang tidak berkonsep menyeluruh. Selain karena biaya dan pendapatan yang diterima petani yang relatif tidak berbeda dibandingkan melaksanakan pola tanam konvensial, juga karena permasalahan yang dialami dalam proses agribisnis yang ada menimbulkan keengganan petani untuk melaksanakannya. Menurut Totok Mardikanto (2009), pembangunan pertanian yang diusahakan pemerintah harus memenuhi beberapa persyaratan dan indikator, yaitu: (1) kejelasan tentang kebijakan pembangunan, (2) penyuluhan pertanian berkelanjutan, (3) pasar pemintaan hasil-hasil pertanian, (4) tersedianya paket teknologi, (5) tersedianya kredit bagi petani, (6) kegiatan penelitian dan pengembangan, dan (7) pembangunan dan pemeliharaan prasarana dan sarana pembangunan pertanian. Kondisi yang terjadi di Desa Tlahab mengindikasikan PMUP sebagai sebuah kegiatan yang berdasarkan pembangunan pertanian yang berkelanjutan belum terlaksana sesuai kaidah dan konsep yang telah ada sebelumnya. 


\section{RESPON PETANI TEMBAKAU TERHADAP KEGIATAN PMUP DI DESA TLAHAB KECAMATAN KLEDUNG KABUPATEN TEMANGGUNG}

Dalam konteks respon petani Desa Tlahab terhadap kegiatan PMUP, dibagi ke dalam tiga klasifikasi utama, yaitu (1) kondisi petani dan lingkungan petani, dalam hal ini adalah kondisi di Desa Tlahab, baik lingkungan, kelompok tani maupun aspek sosial budaya yang berlaku di dalamnya; (2) paket kegiatan PMUP itu sendiri mulai dari konsep, tujuan, teknis kegiatan, penerapannya di lapangan, komoditi di dalamnya dan implikasinya bagi petani jika melaksanakan kegiatan tersebut dalam hal ini ditinjau dari keuntungan secara ekonomi bagi petani pelaksananya, serta (3) kondisi eksternal, dalam hal ini adalah situasi yang terjadi di luar lingkungan petani yang sedikit banyak memberikan dorongan dan masukan bagi petani dalam mengambil keputusan melaksanakan PMUP atau akan menolaknya.

\section{Tahapan Respon Petani di Desa Tlahab Terhadap Kegiatan PMUP \\ Tahap Kognitif}

Pada tahapan kognitif, para petani memberikan penilaian terhadap kegiatan PMUP, penilaian tersebut didasarkan atas pengetahuan petani terhadap kegiatan tersebut sehingga mampu memperkirakan keuntungan dan kerugian apabila melaksanakan kegiatan PMUP. Pengetahuan tentang PMUP dilatarbelakangi oleh (1) kondisi petani itu sendiri, mulai dari pendidikan formal, tingkat kesejahteraannya, budaya setempat yang sudah ada sebelumnya, (2) Kegiatan PMUP itu sendiri, yaitu kesesuaiannya dengan masyarakat dan lingkungan Desa Tlahab, kesesuaian komoditi PMUP, serta sistem pelaksanaan dan sosialisasinya kepada para petani, dan (3) Kondisi lingkungan baik Desa Tlahab itu sendiri, pengalaman petani dalam membudidayakan tembakau serta prospek dari komoditi yang menjadi paket kegiatan PMUP.

Tahap Afektif

Pada tahap afektif, petani mengambil sikap, menilai dan kesimpulan terhadap kegiatan PMUP. Kondisi ini timbul akibat terjadinya perubahan dan pergeseran keadaan akibat adanya kegiatan PMUP. Tahap ini mulai terjadi pada saat kopi arabika hasil pelaksanaan PMUP 2000-2004 mulai memberikan hasil pada tahun 2003-2004. Ada beberapa kondisi yang menyebabkan cara pandang petani cukup positif, antara lain: (1) lahan yang melaksanakan PMUP 2000-2004 mulai menampakkan hasilnya dan dapat memberikan pendapatan yang cukup besar, (2) kondisi agribisnis tembakau mengalami masa surut pada tahun 2005-2009 sehingga petani mulai mencari alternatif pendapatan selain tembakau dan hal tersebut mereka temukan pada pelaksanaan PMUP.

Tahap Psikomotor

Tahap psikomotor merupakan tindakan nyata dalam menanggapi kegiatan PMUP, apakah akan melaksanakan atau menolak kegiatan PMUP. Dari tahapan yang telah ada sebelumnya dan berbagai hal yang melatarbelakanginya. Tahapan psikomotor dapat dilihat saat ini pada saat kegiatan PMUP sudah selesai dilaksanakan di lapangan, sehingga petani hanya berkonsentrasi pada sistem agribisnis mulai dari budi daya, pengolahan, dan pemasaran. Dari tiga subsistem agribisnis komoditi PMUP tersebut, petani merasakan adanya permasalahan dan kendala yang dialaminya. Kondisi riil di Desa Tlahab memperlihatkan bagaimana respon petani terhadap kegiatan PMUP. Hal itu terutama didasari permasalahan yang ada pada pola agribisnis yang ada. Beberapa kendala yang ada dalam agribisnis adalah: (1) kesinambungan produksi, (2) kurang memadainya informasi dan akses pasar, (3) panjangnya saluran pemasaran, (4) rendahnya kemampuan tawar-menawar, (5) berfluktuasinya harga, (6) kurang tersedianya informasi pasar, (7) kurang jelasnya jaringan pemasaran produsen dan/atau pedagang, (8) rendahnya kualitas produksi, (9) rendahnya kualitas sumber daya manusia, dan (10 
ketersediaan modal baik bagi petani maupun kelompok tani, modal menjadi kendala bagi petani mulai dari tahap budi daya sampai dengan pemasaran.

\section{Respon Petani di Desa Tlahab Terhadap Kegiatan PMUP Berdasarkan Waktu Pelaksanaan}

Berdasarkan waktu pelaksanaan kegiatan PMUP dan kondisi eksisting PMUP di Desa Tlahab saat ini, penulis membagi respon petani dalam tiga tahapan utama yaitu tahap afektif, kognitif dan psikomotor. Petani pelaksana kegiatan PMUP terbatas hanya dilakukan para petani yang mendapatkan bantuan komoditi dalam paket PMUP, yaitu kopi arabika, suren dan ternak kambing disertai bibit rumput gajah. Sedangkan para petani yang tidak mendapatkan bantuan baik PMUP 2000-2004 dan PMUP 2009 sama sekali tidak melaksanakan kegiatan tersebut. Ada beberapa hal yang melatarbelakangi antara lain karena tidak mendapatkan paket bantuan PMUP, tidak memiliki lahan, dan yang paling berperan adalah karena para petani secara umum beranggapan bahwa pola PMUP tidak lebih menguntungkan dibandingkan budidaya tembakau yang dilakukan sejak dulu

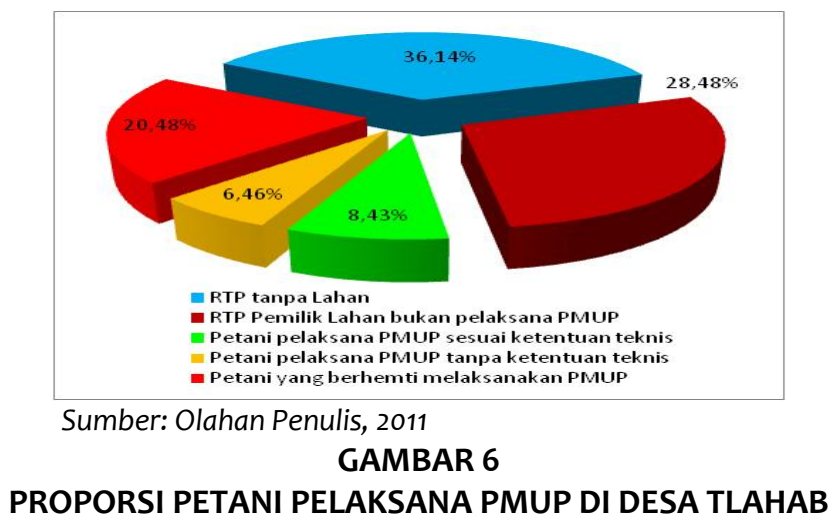

Respon Petani di Desa Tlahab Terhadap Kegiatan PMUP berdasarkan Kondisi Lahan yang Dikelola

Dari pembagian tingkatan respon baik berdasarkan periode waktu pelaksanaan, petani pelaksana kegiatan dan kondisi lahan pertanian yang ada, seperti yang telah dijelaskan di atas, selanjutnya akan dapat dianalisa respon para petani tembakau terhadap kegiatan PMUP.

TABEL 1

KONDISI LAHAN DAN TINGKATAN RESPON PETANI DESA TLAHAB TERHADAP KEGIATAN PMUP DAN LATAR BELAKANGNYA

\begin{tabular}{|c|c|c|c|}
\hline NO & $\begin{array}{l}\text { TINGKATAN } \\
\text { PELAKSANAAN }\end{array}$ & PETANI PELAKSANA & LATAR BELAKANG PILHAN PETANI \\
\hline \multirow[t]{5}{*}{1.} & Melaksanakan & rus & Mendapatkan \\
\hline & $\begin{array}{l}\text { PMUP sesuai } \\
\text { petuniuk teknis }\end{array}$ & $\begin{array}{l}\text { kelompok } \\
\text { sebagian }\end{array}$ & $\begin{array}{l}\text { ekonomis dari pelaksanaan PMUP baik dari } \\
\text { sistem agrobisnisnya maupun pendapatan }\end{array}$ \\
\hline & & pelaksana & lain dari kelompok tani. \\
\hline & & $\begin{array}{ll}2009 \text { dan } & \text { petani } \\
\text { penerima } & \text { paket }\end{array}$ & $\begin{array}{l}\text { 2. Adanya harapan mendapatkan bantuan } \\
\text { sejenis dari pemerintah. }\end{array}$ \\
\hline & & $\begin{array}{l}\text { bantuan dengan } \\
\text { lahan yang relatif } \\
\text { luas. }\end{array}$ & $\begin{array}{l}\text { 3. Masih berharap komoditi PMUP di } \\
\text { kemudian hari akan mengalami kondisi } \\
\text { yang lebih baik. }\end{array}$ \\
\hline 2. & $\begin{array}{l}\text { Melaksanakan } \\
\text { PMUP namun }\end{array}$ & $\begin{array}{l}\text { Petani penerima } \\
\text { bantuan yang tidak }\end{array}$ & $\begin{array}{l}\text { 1. Modal yang dimiliki terbatas sehingga } \\
\text { pemenuhan biaya pengelolaan sebatas }\end{array}$ \\
\hline
\end{tabular}




\begin{tabular}{|c|c|c|c|}
\hline NO & $\begin{array}{l}\text { TINGKATAN } \\
\text { PELAKSANAAN }\end{array}$ & PETANI PELAKSANA & LATAR BELAKANG PILHAN PETANI \\
\hline & $\begin{array}{l}\text { tidak sesuai } \\
\text { dengan } \\
\text { petunjuk teknis } \\
\text { PMUP. }\end{array}$ & $\begin{array}{l}\text { melaksanakan } \\
\text { PMUP sesuai } \\
\text { petunjuk teknis, di } \\
\text { lahannya. }\end{array}$ & $\begin{array}{l}\text { peda besar modal yang dimilkinya. } \\
\text { 2. Ada keraguan melaksanakan PMUP secara } \\
\text { penuh. } \\
\text { 3. Kurangnya keterampilan dan pengetahuan } \\
\text { yang dimiliki dalam mengelola agrobisnis } \\
\text { dengan model PMUP sehingga } \\
\text { pendapatannya rendah. }\end{array}$ \\
\hline 3. & $\begin{array}{l}\text { Tidak } \\
\text { melaksanakan } \\
\text { PMUP }\end{array}$ & $\begin{array}{l}\text { Petani yang tidak } \\
\text { menerima bantuan } \\
\text { dan petani yang } \\
\text { sebelumnya } \\
\text { menerima bantuan } \\
\text { namun kemudian } \\
\text { tidak melaksanakan } \\
\text { kegiatan PMUP di } \\
\text { lahannya, }\end{array}$ & $\begin{array}{l}\text { 1. Tidak mendapatkan paket bantuan PMUP.. } \\
\text { 2. Menganggap budidaya tembakau lebih } \\
\text { menguntungkan. } \\
\text { 3. Keterbatasan modal } \\
\text { 4. Sistem agribisnis yang tidak jelas dan tetap } \\
\text { 5. Peran SKPD terkait dan kelompok tani yang } \\
\text { kurang berperan dalam membantu } \\
\text { permasalahan yang dihadapi para petani. } \\
\text { 6. Keterbatasan pengetahuan dan teknologi } \\
\text { dalam berinovasi mengolah hasil } \\
\text { pertanian.. }\end{array}$ \\
\hline
\end{tabular}

Sumber: Olahan Penulis, 2011

\section{Respon Petani Tembakau Terhadap Kegiatan PMUP di Desa Tlahab}

Unsur pokok respon adalah understanding, awareness, share, dan participation yang ditunjukkan oleh obyek pemilik respon, sehingga apabila obyek respon dalam hal ini adalah petani, terhadap kegiatan PMUP sebagai sebuah konsep diversifikasi pola tanam tembakau yang berbeda jika dibandingkan dengan pola tanam tradisional sebelumnya, dapat dilihat dari dinamika pemahaman, kesadaran, serta peran serta dan partisipasi mereka dalam pelaksanaan kegiatan. Sebagai sebuah kegiatan yang diterapkan dalam kegiatan usaha petani dalam mendapatkan penghasilan, maka PMUP dianggap berhasil jika petani bersedia dan dapat melaksanakan dengan baik model kegiatan PMUP sehingga kesejahteraannya meningkat disertai perbaikan kualitas lingkungan. Sehingga apabila unsur pokok dalam respon belum terpenuhi, dapat dikatakan bahwa respon petani adalah tidak melaksanakan kegiatan PMUP di lahannya.
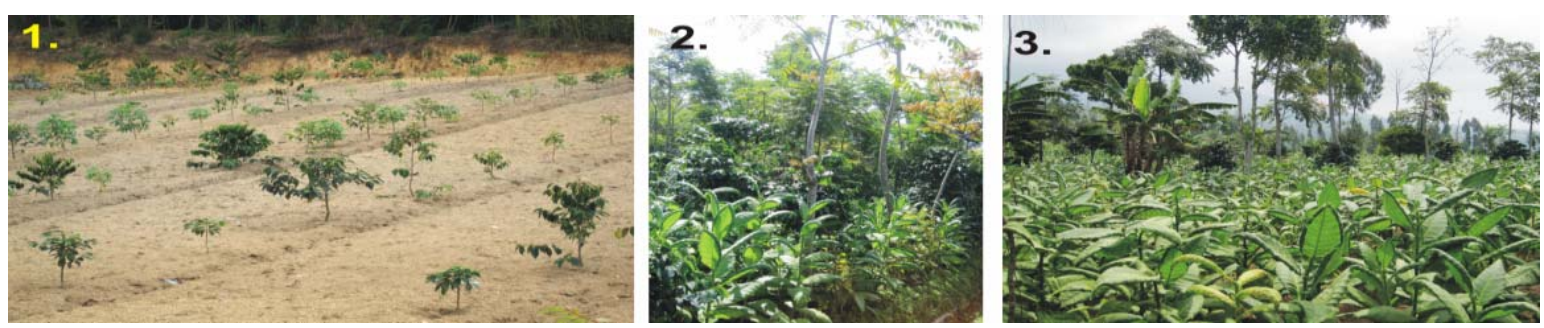

Sumber : Dokumentasi Penulis, 2011

Keterangan: 1. Lahan petani pelaksana PMUP Tahun 2009, .2. Lahan PMUP 2000-2004. 3..Lahan PMUP 20002004 dengan kondisi yang tidak sesuai

GAMBAR 7

PENGELOLAAN LAHAN PMUP BERDASARKAN RESPON PETANI PEMILIK LAHAN TERHADAP KEGIATAN PMUP 


\section{KESIMPULAN}

Pembangunan berkelanjutan di bidang pertanian pada dasarnya adalah sebuah kegiatan usaha pertanian yang melibatkan banyak pihak dengan latar belakang dan motif yang berbeda, mulai dari aspek sosial, budaya, ekonomi, dan lingkungan. Keterpaduan dari semua hal tersebut akan menciptakan kondisi yang mendukung pelaksanaan kegiatan pertanian tersebut. Kegiatan Pengembangan Model Usahatani Partisipatif (PMUP) yang dilaksanakan pemerintah di Desa Tlahab ditujukan untuk meningkatkan kesejahteraan petani dengan meningkatnya pendapatan mereka tanpa menghilangkan budaya pola tanam tembakau yang telah berlangsung lama serta mengurangi kerusakan lingkungan akibat budidaya tembakau. Kegiatan pertanian yang bersifat partisipatif memerlukan peran aktif dan kemauan petani untuk melaksanakan di lahannya. Lahan pertanian dan pengelolaannya bagi para petani adalah sumber pendapatan dan kehidupan mereka, sehingga kesediaan para petani untuk melaksanakan PMUP di lahannya sangat dilatarbelakangi cara pandang, persepsi, dan pengetahuan petani tentang keuntungan, kerugian, dan resiko yang dihadapinya apabila melaksanakan PMUP dibandingkan dengan budaya dan pola tanam yang sebelumnya telah mereka laksanakan dalam jangka waktu lama, yang pada tahap selanjutnya melahirkan respon petani untuk melaksanakannya atau tidak. Secara umum kondisi dan latar belakang petani, kondisi lingkungan sekitar dan pengaruh ekstern menjadi sumber timbulnya respon petani terhadap kegiatan PMUP. Kondisi yang dirasakan para petani dalam menanggapi kegiatan PMUP cenderung mengarahkan untuk tidak melaksanakan kegiatan PMUP, mulai dari keadaan sosial ekonomi petani, kondisi lingkungan sekitar, kinerja kelompok tani, sistem agribisnis PMUP yang tidak memiliki keunggulan dibandingkan budidaya pertanian sebelumnya, mulai dari proses input, pengolahan hingga pemasaran, kinerja kelembagaan dinas pengelola PMUP yang dirasakan kurang perencanaan, koordinasi pelaksanaan dan evaluasinya serta paket kegiatan PMUP yang tidak terkonsep menyeluruh dan belum memberikan kompensasi yang sepadan bagi petani.

\section{DAFTAR PUSTAKA}

Apriyantono, Anton. 2004. Pembangunan Pertanian di Indonesia. Jakarta: Departemen Pertanian.

Arifin, Bustanul. 2004. Analisis Ekonomi Pertanian Indonesia. Jakarta: Kompas Media Nusantara. Baron, A. Robert dan Byrne, Donn. 2003. Psikologi Sosial. Jakarta: Erlangga.

FAO. 1989. Sustainable Development and Natural Resources Management. Twenty-Fifth Conference, Paper C 89/2 simp 2, Rome. Food and Agriculture Organization.

Mardikanto, Totok. 2009. Sistem Penyuluhan Pertanian. Solo: Kerja sama Lembaga Pengembangan Pendidikan (LPP) dan UPT Penerbitan dan Pencetakan UNS (UNS Press).

Moleong Lexy, J. 2007. Metodologi Penelitian Kualitatif. Bandung: Remaja Rosdakarys Offset.

Muhadjir, Noeng. 2003. Metodologi Penelitian Kebijakan dan Evaluation Research. Integrasi Penelitian, Kebijakan ,dan Perencanaan. Edisi I. Yogyakarta: Rake Sarasih.

Rencana Induk Pertembakauan Kabupaten Temanggung. Bappeda Kabupaten Temanggung. 2010.

Salikin, Karwan A. 2003. Sistem Pertanian Berkelanjutan. Yogyakarta: Kanisius.

Sugiyono. 2009. Metode Penelitian Kuantitatif, Kualitatif, dan R\&D. Bandung: Alfabeta 